https://dx.doi.org/10.4314/ijs.v23i2.9

Ife Journal of Science vol. 23, no. 2 (2021)

\title{
CHEMICAL AND MICROBIAL PROPERTIES OF KILN-SMOKED CATFISH IN SELECTED LOCATIONS IN ILORIN METROPOLIS, NIGERIA
}

\author{
*Abiodun, O. A. ${ }^{1}$, Ojo, A. ${ }^{2}$, Kayode, R. M. O. ${ }^{1,}$ Edem, V. E. ${ }^{1,3}$, Shittu, M. O. ${ }^{1}$, Opaleye, Z. A. ${ }^{1}$ \\ and Olayinka, T. N. ${ }^{1}$ \\ ${ }^{1}$ Department of Home Economics and Food Science, University of Ilorin, Kwara State, Nigeria. \\ ${ }^{2}$ Department of Food Science and Technology, Osun State Polytechnic, Iree, Nigeria. \\ ${ }^{3}$ Department of Natural and Environmental Sciences, Crown-Hill University, Ilorin, Kwara State, Nigeria. \\ *Corresponding author's Email: funmiabiodun2003@yahoo.com, abiodun.oa@unilorin.edu.ng Tel: +2348030701354
}

(Received: 23 $3^{\text {rd }}$ March, 2021; Accepted: 30 ${ }^{\text {th }}$ May, 2021)

\section{ABSTRACT}

\begin{abstract}
The use of smoking kiln for drying catfish is on the increase in Nigeria due to its effectiveness in reducing moisture and contamination with toxic compounds during smoking. Chemical properties of kiln-smoked catfish in selected locations in Ilorin metropolis were determined in this study. Kiln-smoked catfish were obtained from four major locations (Oyun, Asa-Dam, Tanke and Agbo-Oba) in Ilorin, Nigeria. The samples were subjected to chemical and polycyclic hydrocarbon content analyses. Dried catfish from all the locations had low moisture and crude fibre contents. There were no significant differences $(p>0.05)$ in the crude fibre contents of the kiln-smoked catfish. Protein contents ranging from 53.72-56.49\% were obtained for the kilnsmoked catfish samples. Fat contents ranged from $9.92-11.77 \%$ while the carbohydrate contents ranged from $19.02-23.59 \%$. Potassium was the most abundant mineral in the samples with no traces of lead and cadmium. Agbo-Oba samples contained the highest pyrene $(2983.215 \mathrm{ng} / \mu \mathrm{l})$ and total polycyclic hydrocarbon (PAHs) $(3349.090 \mathrm{ng} / \mu \mathrm{l})$. Data on steroid fractions indicated that $17 \beta$-estradiol was significantly greater in quantity than those recorded from other steroid fractions. Microbial analyses of the samples revealed the presence of the following pathogenic organisms: Klebsiella spp, Salmonella spp, Shigella spp, Pseudomonas aeruginosa, Staphylococcus aureus, Bacillus cereus, Vibrio spp, Aspergillus niger, penicilium spp, Trichoderma spp which are harmful to man. The use of smoking kiln method improved the nutrients and reduced PAHs in catfish.
\end{abstract}

Keywords: Smoking kiln, Catfish, Chemical properties, Polycyclic hydrocarbon, Mineral elements

\section{INTRODUCTION}

Fish and shellfish are important contributors to the intake of many nutrients worldwide, especially in coastal areas (FAO, 2016). Nogueira et al. (2013) reported fish as an essential food item with easy digestibility, high mineral content, vitamin, quality protein and an excellent dietary source of polyunsaturated fatty acids (PUFAs) which are essential constituents of human diets. Nurnadia et al. (2011) described fish and shellfish as food with low fat and carbohydrate contents but with an excellent source of protein. Fish is a perishable food item with high moisture contents ranging from 56.99-68.46\% (Fapohunda and Ogunkoya, 2006; Akpambang, 2015) and this high amount of moisture could make fish highly susceptible to microbial attacks after harvesting. According to Burt (2003), spoilage in fish could be enzymatic, microbial and chemical in nature. Large percentages $(30-50 \%)$ of post-harvest losses in fish after harvesting, due to poor handling techniques, have been reported by Nwaigwe (2017). However, Bate and Bendall (2010) were of the opinion that proper handling, processing and preservation techniques could minimize the losses.

Akinola et al. (2006) reported different types of preservative methods that could be applied to fish among which are drying, smoking, freezing, chilling, brining etc. Most common of all these processing techniques in Nigeria is smoke-drying (Gawi and Sogbesan, 2017). Palm et al. (2011) describe smoking of fish as one of the ancient technologies used for preserving fish. FAO (2017) defined fish smoking as a process of treating or exposing the fish to smoke from smoldering wood or plant materials. According to Goulas and Kontominas (2005), components such as aldehydes, ketones, alcohols, acids, hydrocarbons, esters, phenols, ethers, etc. are transferred to the surface of the smoked goods and there is subsequent penetration of the smoke into their flesh. Eves and Brown (1993) stated that processing of fish by smoking or drying enhances the nutritive value and promotes digestibility of 
protein. Roda et al. (1999) however, explained that direct exposure of fish to smoke caused higher concentrations of polycyclic aromatic hydrocarbons in the fish as compared to the indirect methods.

Therefore, the use of modern technology in smoking fish is necessary to reduce contamination with toxic substances such as polycyclic aromatic hydrocarbon. Bolaji (2005) suggested that the use of modern equipment such as solar dryers, kilns and ovens is an upgrade on the traditional fish processing technique. In Nigeria, the use of smoking kiln on fish is now common and adopted by fish farmers. Smoking kiln is a fabricated equipment with drying and heating chambers. It had been reported that smoking kiln is safe and the temperature of the chamber is uniformly distributed for effective drying (Adigio et al., 2015). Smoking kiln prevent direct flame to the fish thereby, preventing formation of black soot on the product (Adigio et al., 2015). According to Okereke et al. (2014), smoking kiln prevents poor quality fish product, smoke and heat loss, uneven smoking, accommodate larger volumes of fish and saves time.

Lots of fabricated kiln had been produced and used in Nigeria for bulk production of dried fish. The source of smoke and heating is from sawdust, rice bran, melon husk and charcoal respectively as reported by Olayemi et al. (2013) and Aremu et al. (2013). Apart from the proximate composition of the kiln-smoked fish that have been widely studied, there is limited information on other nutritional value of kiln-smoked fish. This study determined the chemical and microbial properties of kiln-smoked catfish in selected locations from Ilorin metropolis, Nigeria.

\section{MATERIALS AND METHODS}

Kiln-smoked catfish were sourced from the four geographical locations of Ilorin metropolis namely Oyun, Asa-Dam, Tanke and Agbo-Oba

\section{Analyses \\ Proximate and Mineral Determination}

AOAC (2005) methods were used to determine moisture (Method 925.10), fat (Method 2003.05), ash (Method 923.03), Fibre (Method 930.15) and protein (Method 960.52), while carbohydrate was calculated by difference. Mineral was carried out according to the method of Novozamsky et al. (1983).

\section{Polycyclic Hydrocarbon Determination}

Sample preparation was done according to Palm et al. (2011) and the instrument is Agilent Technologies 7890A gas chromatograph system equipped with a Flame Ionization Detector (GCFID) and operating in split less mode. The column used was HP5 (30m x 320um x 0.25um) with a non-polar stationary phase (HP-5MS, 5\% phenyl methyl polysiloxane). The oven temperature was set initially at $60^{\circ} \mathrm{C}$ and held for 1 $\mathrm{min}$. The first ramp rate increased to $210^{\circ} \mathrm{C}$ at 12 ${ }^{\circ} \mathrm{C} / \mathrm{min}$ and second ramp rate increased to $320^{\circ} \mathrm{C}$ at $8{ }^{\circ} \mathrm{C} / \mathrm{min}$ and held for $5 \mathrm{~min}$. Carrier gas was Helium: Nitrogen, while the ignition gases were Hydrogen and compressed air. Total run time was $32.25 \mathrm{~min}$ and detector temperature was $325^{\circ} \mathrm{C}$. The inlet temperature was held at $270{ }^{\circ} \mathrm{C}$ with flow rate of $1.2 \mathrm{ml} / \mathrm{min}$, while injections of $1 \mu \mathrm{l}$ of sample each were performed in the split less mode. Identification of PAHs in the samples was based on comparison of the retention times with those in a standard solution, and quantification on the corresponding areas of the respective chromatograms.

\section{Determination of Steroid using HPLC}

The method of Murad et al. (2016) was used for sterol extraction and determination in catfish samples. HPLC analysis was carried out using Agilent 1200 series HPLC system with Agilent 1260 detector. The column used was BONDAPAK $-\mathrm{C}_{18}$ with dimension $1.7 \mu \mathrm{m}$ x 2.1 $\mathrm{mm} \times 50 \mathrm{~mm}$. The mobile phase was composed of $0.2 \%$ aqueous formic acid (A) and acetonitrile (B). A gradient time program was designed as follows: $0 \mathrm{~min}, 50 \%$ A; $0-3.0 \mathrm{~min}, 50 \%-10 \%$ A; 3.0-5.0 min, $10 \%-50 \%$ A. Injection volume was $10 \mu \mathrm{l}$. The detection wavelength of the detector was set at $254 \mathrm{~nm}$ and flow rate of $0.3 \mathrm{ml} / \mathrm{min}$ at $20^{\circ} \mathrm{C}$.

\section{Microbial Analyses}

Bacteria and fungi load, isolation and identification were done according to Fawole and Osho (2001), while the biochemical tests were performed according to Collins et al. (2002) 


\section{Statistical Analyses}

Proximate, mineral and steroid contents were analyzed in triplicate, while polycyclic hydrocarbon was analyzed in duplicate. Data obtained were subjected to analysis of variance (ANOVA) to determine the mean, standard deviation and significant differences among the samples $(\mathrm{P}<0.05)$ and $(\mathrm{P}<0.0001)$ for steroid . The means were separated using Tukey Test as packaged by SPSS (ver. 17).

\section{RESULTS AND DISCUSSION}

Effect of Location on the Proximate Composition of Smoked Catfish

Proximate composition of kiln-smoked catfish in selected location in Ilorin, Kwara State, Nigeria is shown in table 1 . The results showed that location had significant $(\mathrm{P}<0.05)$ effect on the moisture, ash, fat, protein and carbohydrate contents of catfish. However, there were no significant differences $(\mathrm{P}>0.05)$ in locations with respect to crude fibre of catfish. The results also showed that, catfish obtained from Oyun location had the highest total ash, crude fat and protein than catfish obtained from other locations. Likewise, catfish obtained from Tanke location recorded the highest contents in moisture and carbohydrate than those from other locations.

Moisture contents observed in all the samples were lower than reported values for smoked dried fish. Flowra et al. (2012) reported moisture contents of $14.06-24.58 \%$ for dried fish while Adeyeye et al. (2015) reported moisture contents of $11.86-13.81 \%$ for smoked fish samples. The variation noticed in moisture contents of the catfish can be due to the size, temperature and duration of drying. This result therefore indicated that kiln drying is suitable to remove an appreciable amount of moisture from fish thereby prolonging the shelf-life of the product. Oyun sample had the highest ash content $(6.04 \%)$ while Tanke sample had the lowest ash value (4.92\%). Ash contents observed indicated that the catfish are good source of minerals. Sesugh et al. (2012) and Ikeme (1991) observed ash contents of between $5.4-15 \%$ for dried fish while Nnaji and Ngele (2016) reported lower ash contents ranging from $2.07-3.55 \%$ for dried catfish obtained in the market. Crude fibre contents of the catfish were low and depended on the diet, age and size of the fish. Oyun sample exhibited the highest fat contents while sample from Agbo-Oba had the lowest fat content. Fat contents obtained were within the values $(1.91-17.76 \%)$ reported for marine fish (Flowra et al., 2012). Higher fat contents ranging from $16.5-27.50 \%$ had been reported for smoked catfish (Sesugh et al., 2012; Nnaji and Ngele, 2016). The high fat content in the cat fish could be attributed to the removal of moisture content. High fat contents observed in Oyun sample could lead to short shelf-life as a result of rancidity.

Table 1: Effect of Location on the Proximate Composition of Catfish

\begin{tabular}{lllll}
\hline \begin{tabular}{l} 
Parameter \\
\multicolumn{1}{c}{$(\%)$}
\end{tabular} & \multicolumn{4}{c}{ Location } \\
\cline { 2 - 5 } & Oyun & Asa-Dam & Tanke & Agbo-Oba \\
\hline Moisture & $6.30 \pm 0.04^{\mathrm{c}}$ & $6.49 \pm 0.02^{\mathrm{b}}$ & $7.06 \pm 0.05^{\mathrm{a}}$ & $6.33 \pm 0.01^{\mathrm{c}}$ \\
Total ash & $6.04 \pm 0.02^{\mathrm{a}}$ & $5.39 \pm 0.02^{\mathrm{b}}$ & $4.92 \pm 0.01^{\mathrm{d}}$ & $5.15 \pm 0.03^{\mathrm{c}}$ \\
Crude fibre & $0.38 \pm 0.01^{\mathrm{a}}$ & $0.37 \pm 0.02^{\mathrm{a}}$ & $0.34 \pm 0.04^{\mathrm{a}}$ & $0.41 \pm 0.01^{\mathrm{a}}$ \\
Crude fat & $11.77 \pm 0.05^{\mathrm{a}}$ & $10.51 \pm 0.03^{\mathrm{b}}$ & $10.37 \pm 0.02^{\mathrm{a}}$ & $9.92 \pm 0.04^{\mathrm{d}}$ \\
Crude protein & $56.49 \pm 0.04^{\mathrm{a}}$ & $55.67 \pm 0.05^{\mathrm{b}}$ & $53.72 \pm 0.03^{\mathrm{c}}$ & $55.77 \pm 0.05^{\mathrm{b}}$ \\
Carbohydrate & $19.02 \pm 0.04^{\mathrm{d}}$ & $21.57 \pm 0,14^{\mathrm{c}}$ & $23.59 \pm 0.06^{\mathrm{a}}$ & $22.42 \pm 0.10^{\mathrm{b}}$ \\
\hline
\end{tabular}

Value with the same superscript along the row are not significantly different $(\mathrm{p}<0.05)$ from each other

Oyun sample was significantly different $(\mathrm{p}<0.05)$ from other samples in protein content, while no significant differences $(p>0.05)$ in the protein values observed for samples from Asa-Dam and Agbo-Oba. The protein values observed in this study were similar to the values (30.60-68.05\%) reported by Fapohunda and Ogunkoya (2006); Sesugh et al. (2012); Okereke et al. (2014); Adeyeye et al. (2015); Mohammad and Yusuf (2016) and Nnaji and Ngele (2016). Protein content of the dried smoked catfish depends majorly on the types of feed given to the fish, time and frequency of feeding, maturation size, processing and handling methods. The catfish contain appreciable amount of carbohydrate which could be in form of glycogen. Nutritional composition 
of kiln-smoked catfish had been reported to depend on the source of heat, feeding habit, sex and seasonal variations (Akinneye et al., 2010; Aremu et al., 2013; Abraha et al., 2018). The variation in the proximate composition of the catfish may be due to the type of feed intake of the fish, size, location, maturity and the different processing methods employed.

\section{Effect of Location on the Mineral Composition of Smoked Catfish}

Predominant mineral elements in the samples were potassium and calcium. Other elements detected at low concentrations were iron, copper, zinc, nickel and manganese. Table 2 revealed that sample location had significant $(\mathrm{P}<0.05)$ effects on the mineral contents of catfish examined. The results indicated that catfish samples obtained from Agbo-Oba had the highest iron (0.030 $\mathrm{mg} / \mathrm{ml}$ ) content than the fish obtained from other locations and was significantly different $(\mathrm{p}<0.05)$ from other samples. On the other hand, there were no significant differences $(p>0.05)$ in iron contents in catfish obtained from Oyun, Asa-Dam and Tanke. The differences in the mineral content could be attributed to the habitat, type of feeds used by the farmers in rearing the fish as well as the amount of time and temperature employed during fish smoking process. The absence of lead and cadmium showed that consumption of the fish cannot impose health hazard to the consumers. Castro-gonzález and Méndez-armenta (2008) and Palaniappan and Karthikeyan (2009) suggested that heavy metals determination in fish is very important in order to identify the level and maintain concentration under permissible level. According to the European Union (2006), the maximum tolerable limit (MTL) of lead in fish is $0.3 \mathrm{mg} / \mathrm{kg}$, copper is $0.020 \mathrm{mg} / \mathrm{kg}$ and cadmium, $0.05-0.3 \mathrm{mg} / \mathrm{kg}$ wet weight basis respectively. The heavy metals were not detected in the kiln-smoked catfish in all the locations showing that they are safe for human consumption. The variations in the mineral values could be as a result of the environmental conditions, feed, ecological requirements, metabolism and other factors such as salinity, water pollution level, and sediment (Ashraf etal.2012).

Table 2: Effect of Location on the Mineral Contents $(\mathrm{mg} / \mathrm{ml})$ of Catfish

\begin{tabular}{lllll}
\hline Parameter & \multicolumn{4}{l}{ Location } \\
\cline { 2 - 5 } & Oyun & Asa-Dam & Tanke & Agbo-Oba \\
\hline $\mathrm{Fe}$ & $0.020 \pm 0.000^{\mathrm{b}}$ & $0.025 \pm 0.003^{\mathrm{b}}$ & $0.025 \pm 0.002^{\mathrm{b}}$ & $0.030 \pm 0.001^{\mathrm{a}}$ \\
$\mathrm{Cu}$ & $0.025 \pm 0.003^{\mathrm{bc}}$ & $0.029 \pm 0.004^{\mathrm{b}}$ & $0.040 \pm 0.000^{\mathrm{a}}$ & $0.020 \pm 0.000^{\mathrm{c}}$ \\
$\mathrm{Zn}$ & $0.030 \pm 0.002^{\mathrm{a}}$ & $0.020 \pm 0.004^{\mathrm{b}}$ & $0.020 \pm 0.001^{\mathrm{b}}$ & $0.010 \pm 0.000^{\mathrm{c}}$ \\
$\mathrm{Ni}$ & $0.010 \pm 0.000^{\mathrm{c}}$ & $0.020 \pm 0.002^{\mathrm{a}}$ & $0.010 \pm 0.000^{\mathrm{b}}$ & $0.015 \pm 0.007^{\mathrm{bc}}$ \\
$\mathrm{Mn}$ & $\mathrm{ND}$ & $\mathrm{ND}$ & $\mathrm{ND}$ & $\mathrm{ND}$ \\
$\mathrm{Pb}$ & $\mathrm{ND}$ & $\mathrm{ND}$ & $\mathrm{ND}$ & $\mathrm{ND}$ \\
$\mathrm{Cd}$ & $\mathrm{ND}$ & $\mathrm{ND}$ & $\mathrm{ND}$ & $\mathrm{ND}$ \\
$\mathrm{K}$ & $0.425 \pm 0.007^{\mathrm{a}}$ & $0.295 \pm 0.007^{\mathrm{c}}$ & $0.310 \pm 0.004^{\mathrm{bc}}$ & $0.320 \pm 0.009^{\mathrm{b}}$ \\
$\mathrm{Ca}$ & $0.250 \pm 0.000^{\mathrm{a}}$ & $0.210 \pm 0.014^{\mathrm{c}}$ & $0.225 \pm 0.021^{\mathrm{b}}$ & $0.220 \pm 0.014^{\mathrm{bc}}$ \\
\hline
\end{tabular}

Value with the same superscript along the row are not significantly different $(p<0.05)$ from each other. $\quad$ ND= Not detected

Effect of Location on the Polycyclic Aromatic Hydrocarbons of Smoked Catfish

Polycyclic aromatic hydrocarbon (PAHs) contents of catfish samples from selected locations in Ilorin metropolis is as shown in table 3. The PAHs identified in the catfish samples were Acenaphthne, Acenaphthylene, Anthracene, Benz(a)anthracene, Benzo(b)fluoranthene, Benzo(k)fluoranthene, Chrysene, Dibenz(a,h)anthracene, Fluoranthene, 2Methylnaphthalene, Naphthalene, Phenanthrene, and Pyrene. Out of the 13 PAHs detected, five (5) were identified in Oyun, seven (7) in Asa-Dam, seven (7) in Tanke and nine (9) were identified in Agbo-Oba. Agbo-Oba sample had highest Pyrene (2983.215 ng/ $\mu \mathrm{l})$, Benzo(a)anthracene (182.891 $\mathrm{ng} / \mu \mathrm{l})$, Benzo(b)fluoranthene (61.012 $\mathrm{ng} / \mu \mathrm{l})$, Benz(k)fluoranthene $(12.815 \mathrm{ng} / \mu \mathrm{l})$, Chrysene (28.947 ng/ ll), Anthracene $(25.742 \mathrm{ng} / \mu \mathrm{l})$ and Naphthalene $(25.236 \mathrm{ng} / \mu \mathrm{l})$. Agbo-Oba sample had the highest total PAHs (3349.090 ng/ $\mu \mathrm{l})$ followed by Tanke $(1851.170 \mathrm{ng} / \mu \mathrm{l})$, Oyun $(891.130 \mathrm{ng} / \mu \mathrm{l})$ and Asa-Dam $(347.870 \mathrm{ng} / \mu \mathrm{l})$ in decreasing order. 
Table 3: Effect of Location on Polycyclic Hydrocarbon (ng/ $\mu$ l) of Catfish

\begin{tabular}{lcccc}
\hline PAH & Oyun & Asa-Dam & Tanke & Agbo-Oba \\
\hline Acenaphtene & ND & $0.860 \pm 0.06^{\mathrm{a}}$ & $\mathrm{ND}$ & $\mathrm{ND}$ \\
Acenaphthylene & $\mathrm{ND}$ & $0.510 \pm 0.02^{\mathrm{a}}$ & $0.601 \pm 0.03^{\mathrm{a}}$ & $\mathrm{ND}$ \\
Anthracene & $15.766 \pm 1.10^{\mathrm{b}}$ & $2.611 \pm 0.21^{\mathrm{c}}$ & $15.977 \pm 0.33^{\mathrm{b}}$ & $25.742 \pm 2.50^{\mathrm{a}}$ \\
Benz(a)anthracene & $9.677 \pm 0.40^{\mathrm{c}}$ & $\mathrm{ND}$ & $29.853 \pm 1.20^{\mathrm{b}}$ & $182.891 \pm 1.00^{\mathrm{a}}$ \\
Benzo(b)fluoranthene & $\mathrm{ND}$ & $\mathrm{ND}$ & $58.914 \pm 2.40^{\mathrm{a}}$ & $61.012 \pm 2.01^{\mathrm{a}}$ \\
Benzo(k)fluoranthene & $\mathrm{ND}$ & $5.386 \pm 1.50^{\mathrm{c}}$ & $8.116 \pm 0.31^{\mathrm{b}}$ & $12.815 \pm 0.30^{\mathrm{a}}$ \\
Chrysene & $\mathrm{ND}$ & $\mathrm{ND}$ & $\mathrm{ND}$ & $28.947 \pm 0.52^{\mathrm{a}}$ \\
Dibenz(a,h)anthracene & $\mathrm{ND}$ & $\mathrm{ND}$ & $56.383 \pm 0.30^{\mathrm{a}}$ & $\mathrm{ND}$ \\
Fluoranthene & $606.441 \pm 2.52^{\mathrm{a}}$ & $233.895 \pm 2.25^{\mathrm{b}}$ & $\mathrm{ND}$ & $\mathrm{ND}$ \\
2-Methylnaphthalene & $\mathrm{ND}$ & $\mathrm{ND}$ & $\mathrm{ND}$ & $26.529 \pm 0.81^{\mathrm{a}}$ \\
Naphthalene & $\mathrm{ND}$ & $\mathrm{ND}$ & $\mathrm{ND}$ & $25.236 \pm 0.40^{\mathrm{a}}$ \\
Phenanthrene & $2.313 \pm 0.19^{\mathrm{a}}$ & $1.128 \pm 0.30^{\mathrm{b}}$ & $\mathrm{ND}$ & $2.700 \pm 0.61^{\mathrm{b}}$ \\
Pyrene & $256.929 \pm 3.52^{\mathrm{c}}$ & $103.479 \pm 1.20^{\mathrm{d}}$ & $1681.330 \pm 2.70^{\mathrm{b}}$ & $2983.215 \pm 4.90^{\mathrm{a}}$ \\
Total PAHs & $891.130 \pm 2.62^{\mathrm{c}}$ & $347.870 \pm 2.50^{\mathrm{d}}$ & $1851.170 \pm 3.21^{\mathrm{b}}$ & $3349.090 \pm 3.73^{\mathrm{a}}$ \\
\hline
\end{tabular}

Value with the same superscript along the row are not significantly different $(p<0.05)$ from each other. ND-Not detected

PAHs have been identified as mutagenic and carcinogenic compounds. Benzo(a)pyrene is among the most potent and best documented carcinogen (Food Safety Authority of Ireland, 2015). Warshawsky (2000) listed the following PAHs such a Benzo(a)anthracenes, Benzofluoranthracenes, Benzo(a)pyrenes, Chrysenes, and Dibenz(a,h)anthracene as four to five ring PAHs belonging to carcinogenic compounds. Ndiaye et al. (2015) reported that the use of wood and charcoal to smoke fish increases the risk of contamination with byproducts of combustion such as PAHs and other contaminants. PAHs may be formed during processing and domestic food preparation such as barbecuing, smoking, drying, roasting, baking, frying or grilling. Direct fire-drying and heating processes used during the production of oils from plant origin, fish and meat caused pyrolysis of the dripping oil thereby generating PAHs that is deposited on the surface of the product (Food Safety Authority of Ireland, 2015; Lee et al., 2016; Lawal, 2017). Lee et al. (2016) further concluded that PAHs formation during grilling of meat and fish is dependent on fat contents, cooking duration and temperature used for cooking. According to Food Safety Authority of Ireland
(2015) the maximum allowed PAHs (such as Benzo(a)pyrene, Benz(a)anthracene, Benzo(b)fluoranthene and Chrysene) in smoked fish is $30 \mu \mathrm{g} / \mathrm{kg}$ while maximum limit for Benzo(a)pyrene is $2.0 \mu \mathrm{g} / \mathrm{kg}$, though Benzo(a)pyrene was not detected in all the catfish samples analyzed. Higher values of PAHs found in Agbo-Oba and Tanke may be due to the type of wood used as the source of fuel, temperature, duration and the conditions of the water used in rearing the fish. Temperature and time of smoking are major factors determining pyrolysis reaction taking place during smoking with the formation of polycyclic aromatic hydrocarbons which are deposited on food materials. According to Lawal (2017), higher PAHs in fish may also be attributed to residual PAHs found in rivers, lakes etc due to vehicle emission, coal and biomass combustions. Zenlinkova and Zendi (2015) in their review reported the presence of low molecular PAHs such as Naphthalene, Acenaphthene, Fluorene, and Phenanthrene in some fresh sea fish species. Therefore, location from where the catfishes were sourced had impact on the PAH of the kilnsmoked fish due to the nature of habitat, source of fuel available, processing and handling methods adopted. 


\section{Effect of Location on the Steroids of Kiln- Smoked Catfish}

Steroids in Kiln-smoked catfish were significantly affected by location and steroids fractions (Table 4). Six types of steroids were identified in the catfish samples analyzed. Regardless of the steroid fractions, kiln-smoked catfish obtained from Agbo-Oba had significantly the highest amounts of steroids and followed in decreasing order of magnitude by those of Asa-Dam, Tanke and Oyun respectively. Data on steroid fractions indicated that $17 \beta$-estradiol was significantly greater in quantity than those recorded from other steroid fractions. The testosterone was next in quantity and was also statistically different from other steroid fractions. Significant difference $(\mathrm{P}>0.0001)$ was not recorded between estriol and progesterone but both were significantly higher than keto-testosterone and estrone. Estrone had the least value among the steroid fractions but was statistically similar to that of keto-testosterone.
Consumption of food with residual steroid could pose health problem to the consumer. Duarte et al. (2002) reported serious problem of premature sexual development and ovarian cysts in consumers of meat products with zeranol residue in Puerto Rico. Likewise, Bergman et al. (2013) reported endocrine disorder and cancer as the implication of eating steroids contaminated foods. Hormones are used to increase productivity in fish farming but the chemicals could contaminate the environment, promote endocrine system changes thereby causing environmental, biological and food safety problem (Hogaa et al., 2018). The Joint FAO/WHO Expert Committee on Food Additives (JECFA) established an acceptable daily intake of $0-0.05 \mu \mathrm{g} / \mathrm{kg}$ per body weight intake for 17 $\beta$-estradiol, $0-30 \mu \mathrm{g} / \mathrm{kg}$ per body weight for progesterone and $0-2 \mu \mathrm{g} / \mathrm{kg}$ per body weight for testosterone (JECFA, 2000). The steroid values identified in this study were low when compared to the daily limit established.

Table 4: Steroid ( $\mu \mathrm{g} / 100 \mathrm{~g})$ in Catfish at Selected Locations in Ilorin Metropolis

\begin{tabular}{lll}
\hline Results of variation & Factor & Steroids $(\mu \mathrm{g} / 100 \mathrm{~g})$ \\
\hline Location & Agbo-Oba & $7.49 \times 10^{-4 \mathrm{a}}$ \\
& Asa-Dam & $5.45 \times 10^{-4 \mathrm{~b}}$ \\
& Oyun & $5.13 \times 10^{-4 \mathrm{c}}$ \\
Tanke & $5.38 \times 10^{-4 \mathrm{bc}}$ \\
& $17 \beta$-Estradiol & $19.4 \times 10^{-4 \mathrm{a}}$ \\
& Estriol & $1.74 \times 10^{-4 \mathrm{c}}$ \\
& Estrone & $0.87 \times 10^{-4 \mathrm{~d}}$ \\
& Ketotestosterone & $1.12 \times 10^{-4 \mathrm{~d}}$ \\
& Progesterone & $1.64 \times 10^{-4 \mathrm{c}}$ \\
P-value & Testosterone & $5.26 \times 10^{-4 \mathrm{~b}}$ \\
& Location $(\mathrm{L})$ & $<0.0001$ \\
& Steroid fractions $(\mathrm{S})$ & $<0.0001$ \\
& $\mathrm{~L} * \mathrm{~S}$ & $<0.0001$ \\
\hline
\end{tabular}

Values are presented as mean \pm standard error. Values followed by same superscripts along a column are not significantly different at $\mathrm{p}<0.0001)$. NB: $*=$ interaction.

Effect of Location on the Microbial Properties of Kiln-Smoked Catfish

The result of characterization of bacteria isolates are shown in table 5 . The probable bacteria isolates identified from various locations are as follows: Tanke (Staphylococcus aureus, Pseudomonas aeruginosa and Serratia spp), Agbo-Oba (Klebsiella spp., Salmonella spp., Pseudomonas aeruginosa) and Vibrio spp), Asa-Dam (Klebsiella spp., Pseudomonas aeruginosa, Vibrio spp, Bacillus cereus and Staphylococcus aureus) and Oyun (Klebsiella spp., Pseudomonas aeruginosa, Salmonella spp and Shigella spp.). Based on these results, it could be deduced that Psendomonas aeruginosa is common among the fish samples obtained from various locations.

The presence of Bacillus cereus may arise from the food contact surfaces where the catfish had been exposed to. Wonang et al. (2001) stated that Bacillus cereus has been reported to cause food poisoning. 
On the other hand, Mbachu et al. (2014) reported that toxins produced by Bacillus sp. are capable of causing some diseases such as pneumonia and bronchopneumonia. The presence of Klebsiella sp. is an indication of poor handling practices among handlers and sellers of kiln-smoked catfish, while the presence of Psendomonas specie has also been implicated in food spoilage (Mbachu et al., 2014). The results in table 5 show that kiln-smoked catfish in these locations were colonized by Pseudomonas aeruginosa. Their presence is of public health significance, because they are capable of causing infections such as food-borne intoxication (Edem et al., 2017). According to Thi et al. (2020), Pseudomonas aeruginosa is a Gram negative opportunistic pathogenic organism causing acute and chronic infections when ingested which could compromise immune systems.

Staphylococcus aureus, Salmonella spp., Vibrio spp. and Shigella $s p p$. were isolated from kiln-smoked catfish. This could be as a result of handling, transportation as well as exposure of the kilnsmoked catfish to the dirty environment. These organisms are of public health significance as they are considered the leading cause of food-borne disease outbreak worldwide (Karagozlu et al., 2007). The presence of Shigella sp. had been reported to be detrimental to the health of consumers (Arlington, 2007). The FDA standard limit for Salmonella spp and Vibrio spp in food is 0.0 $\mathrm{Cfu} / \mathrm{ml}$ (FDA, 2001). The presence of these organisms in kiln-smoked catfish is currently of public concern.
Kadariya et al. (2014) reported that toxin production strain of Staphylococcus is the leading cause of gastro enteritis following handling of food by the person who harbors the microorganism in the nose and on the skin. Figure 1 and table 6 showed the bacteria and fungi isolates. Predominant fungal was Penicillium spp while others include Trichoderma spp, Geotricum albidum, Fusarium oxysporium, Aspergillus niger and Fusarium oxysporium. The microbial loads of kilnsmoked catfish are presented in table 7 . The bacteria counts ranged from $1.9 \times 10^{6}$ to $2.0 \mathrm{x}$ $10^{7} \mathrm{cfu} / \mathrm{g}$ for Tanke location; $1.710^{7}$ to $6.4 \mathrm{x}$ $10^{7} \mathrm{cfu} / \mathrm{g}$ for Agbo-Oba location. The bacteria count recorded for Asa-Dam and Oyun were from $3.7 \times 10^{7}$ to $7.0 \times 10^{7}$ and $2.0 \times 10^{6}$ to $8.0 \times 10^{6} \mathrm{cfu} / \mathrm{g}$ respectively.

The fungal count obtained in this study for Tanke location was between $2.5 \times 10^{3}$ and $2.2 \times 10^{4} \mathrm{cfu} / \mathrm{g}$; Agbo-Oba location from $8.2 \times 10^{3}$ to $3.6 \times 10^{4}$ $\mathrm{cfu} / \mathrm{g}$; Asa-Dam location ranged from $1.0 \times 10^{3}$ to $1.4 \times 10^{3} \mathrm{cfu} / \mathrm{g}$ and Oyun location ranged from 0.0 $\mathrm{x} 10^{2}$ to $2.0 \times 10^{3} \mathrm{cfu} / \mathrm{g}$.

In order to prevent the occurrence of food-borne diseases, Elijah et al. (2020) posited the necessity to ensure that foods sold to consumers are hygienic and safe for human consumption. Therefore, the hygienic quality and the associated potential health hazards of food could be linked to the microbial load and the presence of pathogenic microorganisms in foods (Hoque et al., 2015). 

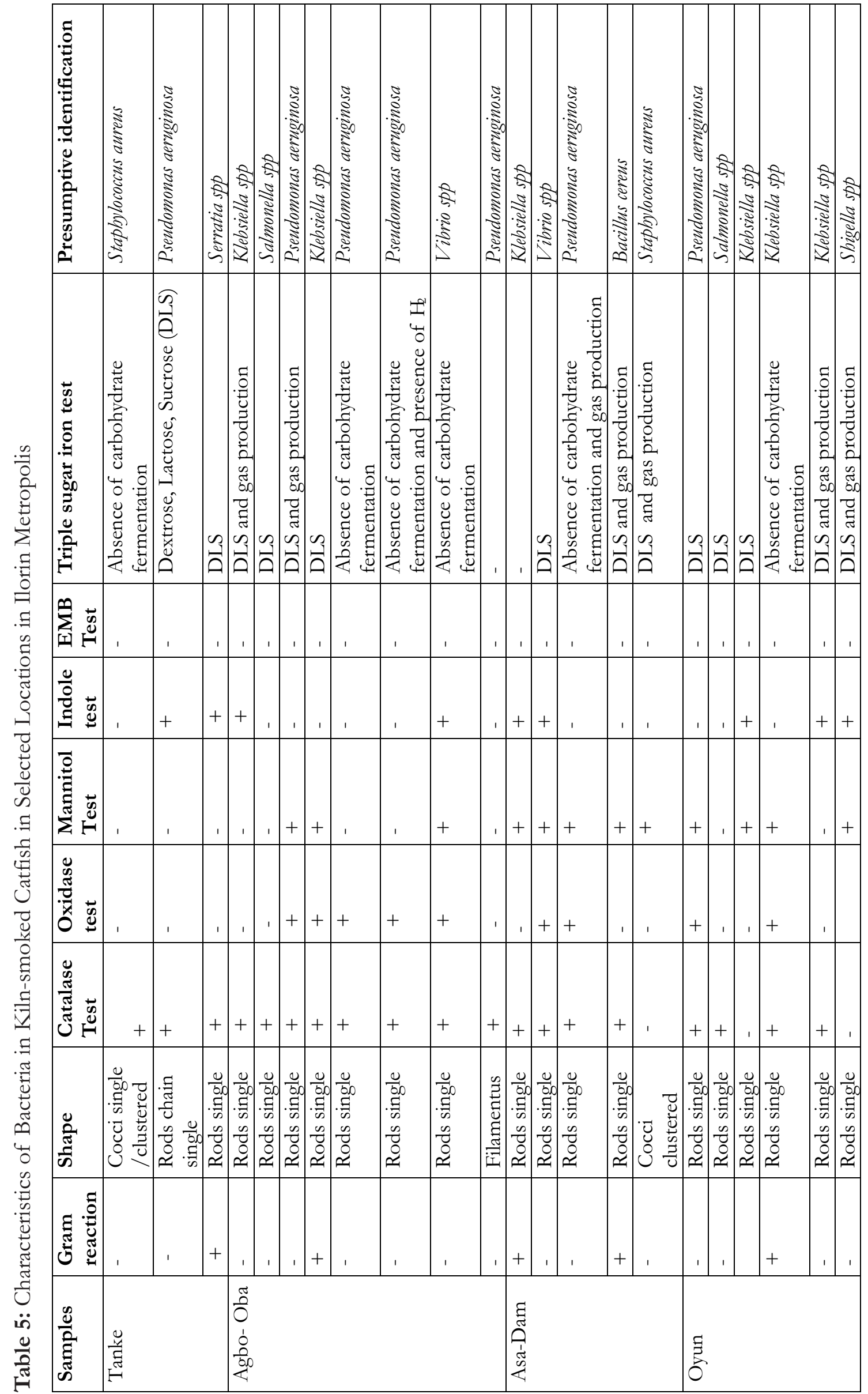
Table 6: Bacteria and Fungi Isolates from Dried Catfish obtained from different Locations in Ilorin Metropolis

\begin{tabular}{lll}
\hline Location & Bacterial Isolate & Fungi Isolate \\
\hline Tanke & Staphylococcus aureus, Pseudomonas aeruginosa, & Trichoderma spp, Geotricum albidum, \\
& Serrataspp & Fusariumoxysporium \\
Agbo-Oba & Klebsiella spp, Salmonella spp, Vibrio spp, & Aspergillus niger, Fusarium oxysporium, Penicillium \\
& Pseudomonas aeruginosa & spp \\
Asa-Dam & Klebsiella spp, Vibrio spp, Pseudomonas aeruginosa, & Penicillium spp \\
& Staphylococcus aureus, Bacillus cereus & \\
Oyun & Klebsiella spp, Salmonella spp, Shigella spp, & Penicillium spp, Trichoderma spp \\
& Pseudomonas aeruginosa & \\
\hline
\end{tabular}

Table 7: Microbial Load of Kiln-Smoked Catfish from Selected Location in Ilorin Metropolis

\begin{tabular}{|c|c|c|c|c|}
\hline \multirow[t]{2}{*}{ Location } & \multicolumn{2}{|c|}{ Bacteria Count (cfu/g) } & \multicolumn{2}{|c|}{ Fungi Count (cfu/g) } \\
\hline & $10^{-5}$ & $10^{-6}$ & $10^{-2}$ & $10^{-3}$ \\
\hline Tanke & $1.9 \times 10^{6}$ & $2.0 \times 10^{7}$ & $2.5 \times 10^{3}$ & $2.2 \times 10^{4}$ \\
\hline Agbo-Oba & $1.7 \times 10^{7}$ & $6.4 \times 10^{7}$ & $8.2 \times 10^{3}$ & $3.6 \times 10^{4}$ \\
\hline Asa-dam & $3.7 \times 10^{7}$ & $7.0 \times 10^{7}$ & $1.4 \times 10^{3}$ & $1.0 \times 10^{3}$ \\
\hline Oyun & $2.0 \times 10^{6}$ & $8.0 \times 10^{6}$ & $0.0 \times 10^{2}$ & $2.0 \times 10^{3}$ \\
\hline
\end{tabular}

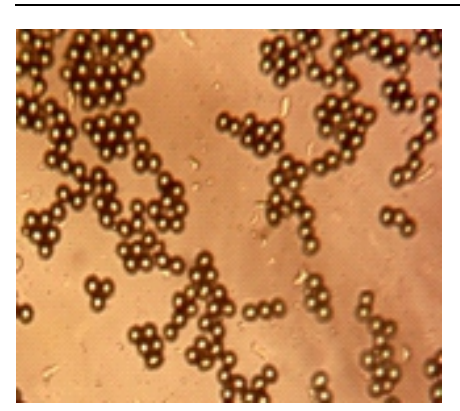

Trichodermaspp

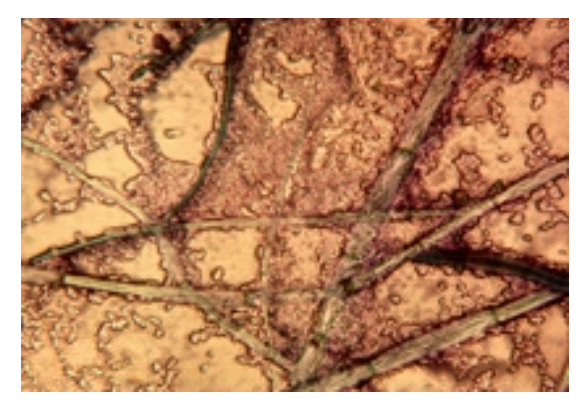

Fusarium oxysporium

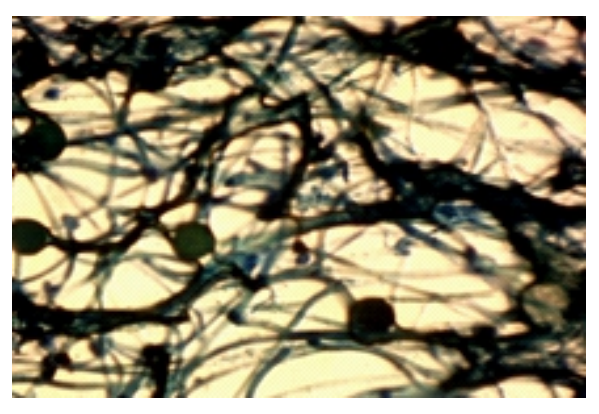

Pennicillium spp

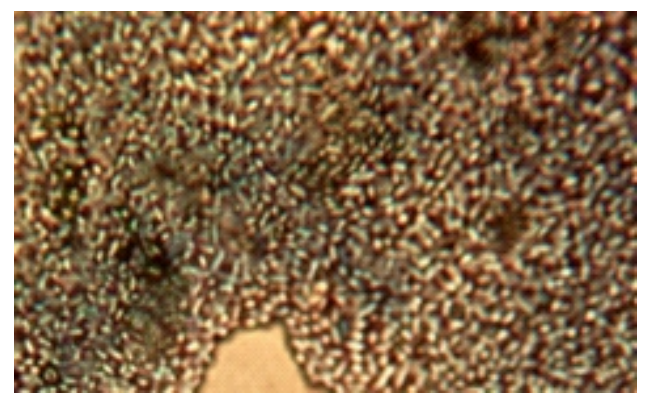

Aspergillus niger

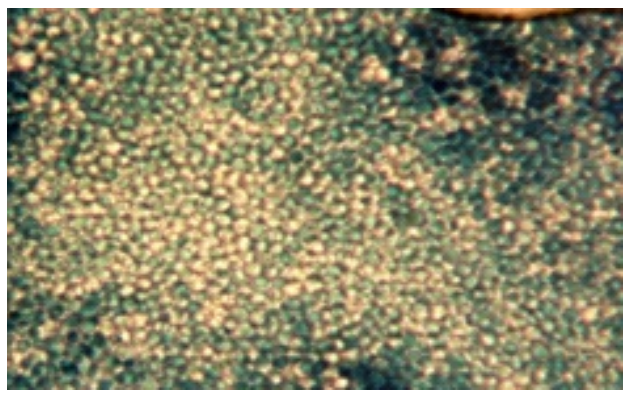

Geotricum albidum

Figure 1: Fungi Isolates from Kiln-smoked Fish

\section{CONCLUSIONS}

With this study, it could be deduced that the parameters analyzed varied according to location, and this may be due to the feed, fish size, maturity, source of fuel, exposure of habitat to pollutants, processing and handling techniques etc. Appreciable amount of protein were retained after smoking with low moisture contents. The use of smoking kiln did not totally eliminate the polycyclic aromatic hydrocarbon (PAH) contamination in the catfish during smoking but greatly reduced PAH when compared to the quantities recorded using traditional methods. Mineral contents of the kiln-smoked catfish 
depend majorly on the habitat, feed and location. Heavy metals were not detected in the catfish samples making the product safe for human consumption. Moreover, steroid contents of the catfish samples were low and could not impose any health risk on the consumers. The microbial isolates indicated that the kiln-smoked catfish samples were contaminated during handling and processing. Therefore, enlightenment and sensitization of fish processors on hygiene is very paramount in order to prevent outbreak of food borne diseases.

\section{REFERENCES}

Abraha, B., Admassu, H., Mahmud, A., Tsighe, N., Shui, X.W. and Fang,Y. (2018). Effect of processing methods on nutritional and physico-chemical composition of fish: a review. MOJ Food Process Technology, 6(4): 376-382.

Adeyeye, S. A. O., Oyewole, O. B., Obadina, A. O., Omemu, A. M., Adeniran, O. E., Oyedele, H. A. and Abayomi S. O.(2015). Quality and safety assessment of traditional smoked fish from Lagos State, Nigeria. International Journal of Aquaculture, 5(15): 19

Adigio, E.M., Adeyemo, A.O. and Awosusi, D. (2015). Design, fabrication and operation of a smoking kiln. International Journal of Engineering and Technical Research, 3(3): 293296

Akinneye, J.O., Amoo, I.A. and Bakare, O.O. (2010). Effect of drying methods on the chemical composition of three species of fish (Bonga spp., Sardinella spp. and Heterotis niloticus). African Journal of Biotechnology, 9(28): 4369-4373.

Akinola, O.A., Akinyemi, A.A. and Bolaji, B.O. (2006) Evaluation of Traditional and solar drying systems towards enhancing fish storage and preservation in Nigeria (Abeokuta Local Government as a case study). Journal of Fisheries International 1: 4449.

Akpambang, V.O.E. (2015). Proximate composition of some tropical fish species. DerChemica Sinica, 6(4), 125-129

Ashraf, M.A., Maah, M.J. and Yusoff, I. (2012). Bioaccumulation of heavy metals in fish species collected from former tin mining catchment. International Journal of EnvironmentalResearch, 6(1):209-218.

AOAC (2005). Official method of Analysis. 18th Edition, Association of Officiating Analytical Chemists, Washington DC.

Aremu, M.O., Namo, S.B., Salau, R.B., Agbo, C.O.and Ibrahim, H. (2013). Smoking methods and their effects on nutritional value of African Catfish (Clarias gariepinus). The Open Nutraceuticals Journal, 6: 105-112

Arlington, V. A. (2007). Response to the questions posed by the food safety and inspection service regarding consumer guidelines for the safe cooking of poultry products. Journal of Food Protection, 70(1):251260

Bate, E.C and Bendall, J.R. (2010). Changes in fish muscle after death. British Medical Bulletin, (12): 2305.

Bergman, A., Heindel, J. J., Jobling, S., Kidd, K. A. and Zoeller, R. T. (2013). State of the science of endocrine disrupting chemicals. Geneva, Switzerland: WHO Press, World Health Organization.

Bolaji, B.O. (2005). Performance evaluation of a simple solar dryer for food preservation. Book of Proceedings of 6th Annual Engineering Technology, Federal University of Technology, Minna, Nigeria, pp: 8-13.

Burt, J.R. (2003). Hypoxanthine a biochemical index of fish quality. Process Biochemistry, 11(10): 23-25.

Castro-gonzález, M. I., and Méndez-armenta, M. (2008). Heavy Metals: Implications associated to fish consumption. Environmental Toxicology and Pharmacology, 26: 263-271

Collins, C.H., Lyne, P.M and Grange, J.M. (2002). Microbiological Methods (6 ${ }^{\text {th }}$ Edition). Butterworth and Co Ltd. London Pp.2325.

Duarte, K. M. R., da Silva, F. M. S. M. and Meirelles, C. F. (2002). Resíduos de anabolizantesnaprodução animal: Importância e métodos de detecção [Anabolic residues in livestock prodution: relevancy and detection methods. Ciência Rural, 32(4): 731-737.

Edem, V. E., Elijah, A. I. and Umoh, S. H. (2017). Microbial quality of kunun-zaki sold in 
Eiyenkorin, Kwara State, Nigeria. Nigerian Journal of Agriculture, Food and Environment. 13(2):112-116.

Elijah, A. I., Ben, A. and Edem, V. E. (2020). Investigation of microbiological quality of selected street vended foods sold in Uyo metropolis, Akwa Ibom State, Nigeria. Bacterial Empire, 3(3): 32-40.

European Union (2006). Setting maximum levels for certain contaminants in foodstuffs. Commission Regulation (EC) No 1881/2006; OJ L 364, p. 5

Eves, A. and Brown, R. (1993). The effect of traditional drying processes on the nutritional value of fish. Tropical Science, 33: 183-189.

FAO (2016). The State of World Fisheries and Aquaculture 2016. Contributing to Food Security and Nutrition for All. Fisheries and Aquaculture Department, Food and Agriculture Organization of the United Nations, Rome.

FAO (2017). Food and Agriculture Organization of United Nations. Policy Brief No. 1

Fapohunda, O.O. and Ogunkoya, M. (2006). Effect of smoke-drying on the proximate composition of Tilapia zillii, Parachannaobscura and Clarias gariepinus obtained from Akure, Ondo-State, Nigeria. Animal Research International, 3 (2): 478-480

Fawole, M.O. and Oso, B.A. (2001). Laboratory manual of microbiology. Spectrum Books Limited. Pp 15-21;26-33.

FDA (2001). Guidance for Industry: Food labeling: safe handling statements, labeling of shell eggs: refrigeration of shell eggs helds for retail distribution: small entity compliances guides. Food and Drugs Administration. Documents/FoodLabelingNutrition/ucn059055.

Flowra, F.A., Nahar, D.G., Tumpa, A.S. and Islam, M.T. (2012).Biochemical analysis of five dried fish species of Bangladesh. Rajshabi University Journal of Zoology, 31:09-11

Food Safety Authority of Ireland (2015). Polycyclic hydrocarbon (PAHs) in food. Toxicological Factsheet Series, issue No 2, 1-10

Gawi, G.O. and Sogbesan, O.A. (2017). Fish processing and preservation techniques selected fishing communities along the Upper Benue River, Taraba State. Poultry Fisheries Wildlife Sciences, 5: 184.
Goulas, A.E. and Kontominas, M.G. (2005). Effect of salting and smoking-method on the keeping quality of chub mackerel (Scomber japonicus): biochemical and sensory attributes. Food Chemistry, 93 : 511-520.

Hoga, C.A., Almeidab, F.L. and Reyes, F.G.R. (2018). A review on the use of hormones in fish farming: Analytical methods to determine their residues. Cyta-Journal of Food, 16(1): 679-691

Hoque, A., Khatun, A., Mohammad, A., Masood, T., Khan, A. \&Faruquee, H. (2015). Microbiological hazard analysis and exposure assessment of street vended ready-to-eat foods in Dhaka City, Bangladesh. American-Eurasian Journal of Agricultural and Environmental Sciences, 15(9): 1725-1731.

Ikeme, A. I. (1991). Studies on the fragmentation of smoked fish: In processing of the FAO Expert Consultation on fish. Technology in Africa, no 467

JECFA (2000). Joint FAO/WHO Expert Committee on Food Additives. Evaluation of certain veterinary drug residues in food. World Health Organization Technical Report Series 893. Geneva

Kadariya, J., Smith, T. and Thapaliya, D. (2014). Staphylococcus aureus and staphylococcal food-borne disease: an ongoing Challenge in Public Health. BioMed Research International, Pp. 1-9.

Karagozlu N., Karagozlu C. and Ergonul B. (2007). Survival characteristics of E. coli O157:H7, S. typhimurium and S. aureus during kefir fermentation. Czech Journal of Food Sciences, 25(4): 202-207.

Lawal, A.T. (2017). Polycyclic aromatic hydrocarbon: a review. Cogent Environmental Science, 3:1-89

Lee, J.G., Kim, S.Y., Moon, J.S., Kim, S.H., Kang, D.H. and Yoon, H.J. (2016). Effect of grilling procedures on levels of polycyclic aromatic hydrocarbon in grilled meat. Food Chemistry, 199: 632-638

Mohammad, .H. and Yusuf, M.S. (2016). Proximate evaluation of some economical seafood as a human diet and as alternative prospective valuable of fish meal. Journal 
of Fisheries and Aquatic Science, 11:12-27

Mbachu, A. E., Etok, C. A., Agu, K. C., Okafor, O. I., Awah, N. S., Chidi-Onuorah, L. C., Ekwueme, V. C., Okpala, J., Ogbue, M. O. and Ikele, M. O. (2014). Microbial quality of kunu drink sold in Calabar, Cross River State, Nigeria. Journal of Global Biosciences, 3(2): 511-515.

Murad, H.O., Muhamad, F.A., Hamadameen, A.Y. (2016). Identification and quantification of anabolic steroids in imported frozen beef muscles in sulaimani market using HPLC. Pakistan Journal of Food Sciences, 26(2): 72-82

Ndiaye, O., Komivi, B. S. and Ouadi, Y. D. (2015). The FAO-Thiaroye Processing Technique (FTT-Thiaroye). Rome: Food and Agriculture Organization of the United Nations.

Nnaji, J.C. and Ngele, J. (2016). Proximate and metal composition of smoked fish samples in Umuahia, Nigeria. American Journal of Food Science and Health, 2(5): 102 106

Nogueira, N., Cordeiro, N. and Aveiro, M.J. (2013). Chemical composition, fatty acids profile and cholesterol content of commercialized marine fishes captured in North-Eastern Atlantic. Journal of Fisheries Sciences, 7(3): 271-286

Novozamsky, I., Houba, V. J. G., Van, E. C. K. \& Van, V. W. (1983). Plant nitrogen and phosphorus in plant tissue, novel digestion technique for multi-element. Plant Analysis and Communication in Soil Science, 14: 239-248.

Nurnadia, A.A., Azrina, A. and Amin, I. (2011). Proximate composition and energetic value of selected marine fish and shellfish from the West coast of Peninsular Malaysia. International Food Research Journal, 18: $137-148$

Nwaigwe, U. (2017). Fish preservation and processing. CyTA - Journal of Food, 1-40

Olayemi, F.F., Raji, A. O., Oyelese, O.A., Oyewole, S. N. and Omodara, M. A. (2013). Effective fish smoking kiln for developing country. International Journal of Engineering and Technical Research, 4(1): 1-4

Okereke, A.N., Okpara, J.Y. and Ogumuka, S.O. (2014). Comparative Nutritional
Composition of Smoked Catfish (Clarias gariepinus) Produced from NIOMR smoking kiln and local cut drum oven. American Journal of Food Technology, 9: 377381.

Palaniappan, P. R. and Karthikeyan, S. (2009). Bioaccumulation and depuration of chromium in the selected organs and whole body tissues of freshwater fish Cirrbinus mrigala individually and in binary solutions with nickel. Journal of Environmental Sciences, 21(2): 229-236.

Palm, L.M.N., Carboo, D., Yeboah, P.O., Quasie, W.J., Gorleku, M.A. and Darko, A. (2011). Characterization of Polycyclic Aromatic Hydrocarbons (PAHs) Present in Smoked Fish from Ghana. Advance Journal of Food Science and Technology, 3(5):332-338

Roda, A., Simoni, P.E., Ferri, N., Girotti, S., Ius, A., Rauch, P., Poplstein, M., Pospisil, M., Pipek, P., Hoche, I. and Fukal, L. (1999). Determination of PAHs in various smoked meat products and different samples by enzyme immunoassay. Journal of Science of Food and Agriculture, 79: 58.

Sesugh, A., Luter, L., Ishaq, E. and Sunday, Y. (2012). proximate analysis of smoked and unsmoked fish ( catfish and tilapia) in Ombi river Lafia Nassarawa state, Nigeria,. Elixir Food Science, 53, (2), 1180111803

Thi, M.T.T., Wibowo, D. and Rehm, B.H.A. (2020). Pseudomonas aeruginosa biofilms. International Journal of Molecular Science, $21-25$

Warshawsky, D. (2000). Polycyclic and hetercyclic aromatic hydrocarbon. John Wiley \& Sons, Inc. https://doi.org/ 10.1002/0471435139.tox052

Wonang, D. L., Amienyo, C. A., Ekeleme, O. P. and Dazol, D. G. (2001). Bacteriological assessment of "kunu" a local beverage sold in Jos, Plateau State. Journal of Environmental Sciences, 4(1): 5-7.

Zenlinkova, L. and Zendl, T. (2015). The Occurrence of 16 EPA PAHs in Food-A Review. Polycyclic Aromatic Compounds, 35(2-4): 248-284. 